\title{
Welcoming animals back to the city: Navigating the tensions of urban livestock through municipal ordinances
}

\author{
William H. Butler, Department of Urban and Regional Planning, Florida State University
}

Submitted 26 April 2011 / Accepted 2 October 2011 / Published online 8 February 2012

Citation: Butler, W. H. (2012). Welcoming animals back to the city: Navigating the tensions of urban livestock through municipal ordinances. Journal of Agriculture, Food Systems, and Community Development, 2(2), 193-215. http://dx.doi.org/10.5304/jafscd.2012.022.003

Copyright (C) 2012 by New Leaf Associates, Inc.

\begin{abstract}
Since the Industrial Revolution, livestock has been driven out of urban and semi-urban areas in the United States. Recently, calls for localizing the food system have led to a rise in urban agriculture, and livestock is finding its way back into the city. The return of livestock to urban areas is rife with tensions, including concerns about public health and challenges to dominant perspectives about the separation of urban from rural life. Through an analysis of municipal codes, this paper identifies how some communities have navigated challenges associated with welcoming livestock back into the city. Specifically, the paper analyzes how codes regulate livestock through prohibitions of certain types of animals, zoning to establish where in the municipality livestock can be kept, site-level restrictions that define property characteristics required to keep productive animals, and
\end{abstract}

William H. Butler, Assistant Professor, Department of Urban and Regional Planning, Florida State University, Tallahassee, Florida 32301 USA; +1-850-644-9801; wbutler@,fsu.edu requirements for managing livestock and their accessory structures on the property. The analysis demonstrates that no two municipalities approach the urban livestock question in the same way; however, each seeks to place limits on raising livestock in urban areas through some combination of regulatory land use tools. The paper concludes with a broader discussion of how the regulations address key tensions associated with our understanding of the urban-rural divide and competing claims on public health.

\section{Keywords}

animal control, food systems planning, land use regulations, public health, urban livestock, zoning

\section{Introduction}

Sure, my chickens lay eggs — but the flock has spawned an occasional rooster that crowed loudly and often, starting at 4 a.m. Bees do result in honey and wax and better pollination — but they have also stung 
people from time to time. The garden: verdant cornucopia on one hand, rodentattracting breeding ground on the other. (Carpenter, 2009, p. 5)

In describing her efforts to establish a small urban farm in Oakland, California, Novella Carpenter (2009) eloquently and succinctly captures the tensions that arise with raising livestock in urban environments. Ironically, Carpenter, a well-known advocate of local food and urban farming, engaged in some of her own agricultural activities illegally until recently, when she raised the funds to obtain a conditional use permit for her garden, animals, and associated enterprise (Kuruvila, 2011). Since then, officials in Oakland have decided to take up the question of urban agriculture more comprehensively and develop ordinances that will "tackle the full dimensions of the urban food movement, which is animals and vegetables" according to the city's planning director (as quoted in Kuruvila, 2011, para. 7).

Oakland is not alone in revisiting animal control and land use ordinances in order to respond to a growing demand for producing food in urban and suburban backyards and vacant lots. In the last decade, many municipalities have revised plans and ordinances in order to allow livestock raising within urbanized areas. A new articulation of an old concern arises with this return of agricultural production to urban and semi-urban ${ }^{1}$ environments. While urban livestock can be the source of high quality, local, and arguably tastier protein, the potential for disease, pestilence, odor, and noise nuisance from husbandry activities has not gone away. This paper explores how cities have responded to the growing demand for small-scale animal husbandry in urban and semi-urban areas while navigating the tensions associated with our understanding of urban and rural space and livelihoods as well as competing claims regarding public health.

\footnotetext{
${ }^{1}$ See Meeus and Gulinck (2008) for a review of semi-urban areas loosely defined as landscapes between urban and rural characteristics.
}

The paper begins with a literature review that briefly explores the history of animals in the city. This review focuses on both technological advancements and regulatory approaches that led to the relatively recent expulsion of livestock, and then outlines various reasons why some urban dwellers are advocating their return. An explanation of the methods used for collecting and analyzing municipal ordinances follows. Then, the analysis describes how municipal codes regulate livestock through prohibitions of certain types of livestock, through zoning to establish where in the municipality livestock can be kept, through sitelevel restrictions that define property characteristics required to keep livestock, and through a specification of livestock-keeping practices for managing both livestock and their accessory structures on the property. The discussion and implications section reflects on how the ordinances address some of the inherent challenges associated with livestock keeping in urban and semi-urban environments. In particular, it suggests that the tensions associated with the urban-rural divide and public health will be core challenges that will face planners and advocates who seek to expand opportunities for urban livestock keeping. The conclusion touches on some of the broader implications of this movement to allow livestock back into the city and ways in which municipalities seek to navigate the potential discord associated with the blurring of urban and rural life.

\section{Literature Review}

\section{Moving Livestock out of the City}

For centuries, cities were planned in ways that would ensure the protection of and direct access to agriculturally productive lands. The urban population lived and died by the food that was produced nearby, and much of early city administration aimed to ensure an adequate supply of food (Diamond, 2005; Smit, Nasr, \& Ratta, 2001; Steel, 2009). Until the advent of long-term preservation and efficient long-distance transportation, people needed to live close to where their food was grown or husbanded. While imported grain has sustained basic food needs in cities at least since ancient Rome, other foods, such as fruits, vegetables, milk, 
and meat, were often too perishable to travel far. In order to have access to animal-based protein, pre-industrial city dwellers put up with the nuisances of livestock. Noise, odors, pestilence, and disease were widespread as animals (and their wastes) were integral to life in the city (Steel, 2009).

With technological advancements in transportation during the latter half of the nineteenth century, the dependence on proximal sources of food began to wane in industrializing countries. Agriculture and its ancillary processes began moving out of town, or at least as far as the new railroads reached. While the transition was neither immediate nor totalizing, a great majority of both large- and smallscale farming activities moved into the hinterlands, keeping their ties to urban consumers via a burgeoning network of railroads (Cronon, 1991; Steel, 2009).

Following World War II, several factors led to further movement of livestock operations away from cities. Urban consumers began to move out to suburbs in increasing numbers, leading to the conversion of farmland to development and reducing the available land near cities on which to farm (Kaufman, 2004; Mendes, Balmer, Kaethler, \& Rhoads, 2008; Randolph, 2012). Moreover, refrigerated storage systems on transport and, later, in homes, meant that animal products, including fresh meat and milk, could be shipped long distances and kept for extended periods of time (Cronon, 1991; Pothukuchi \& Kaufman, 1999).

Meanwhile, with increasing industrialization of food production and experimentation in concentrated animal production facilities, more and more livestock began to be raised in concentrated animal feeding operations (CAFOs). CAFOs increased efficiencies by reducing the amount of land necessary for raising each animal. However, to maximize economies of scale, these facilities needed large land areas to house hundreds or thousands of animals at each facility. What had been a landintensive agricultural practice on a per-unit basis slowly became a medical and industrial process undertaken in the hinterlands on concentrated feedlots, with animals fed grains laced with antibi- otic cocktails and growth hormones as they lived on plantless plots until slaughter (Pollan, 2006). Factory farming and industrial food processing increased economies of scale, reduced prices, and facilitated a transition toward an urban diet heavily based on meat (Nestle, 2006; Schlosser, 2001; Steel, 2009). Furthermore, it reinforced the exodus of urban livestock as urban farmers could not compete with the prices of their industrial competitors.

Finally, supermarkets took control of the food distribution system, linking customers with an increasingly globalized food market and concentrating a variety of food products under one roof (Dunkley, Helling, \& Sawicki, 2004; Hodgson, Campbell, \& Bailey, 2011; Pothukuchi \& Kaufman, 1999; Steel, 2009). With their global distribution chains, supermarkets could bring animal products to market from hundreds or even thousands of miles away. The need for a local cattle herd or chicken yard effectively had become obsolete.

In the latter half of the twentieth century, a global industrial food system emerged, and consumers were introduced to a whole new relationship with food. Fast food, processed foods, year-round vegetables and fruits, and increased variety from exotic locales became the norm for urban consumers throughout the developed world (Nestle, 2006; Schlosser, 2001; Steel, 2009). Abundance and convenience defined the new era. The modern industrial food system had overcome the necessity of proximity, in many ways liberating people from local social-ecological constraints in the production of food and eliminating the need for animal husbandry within city limits.

\section{Municipal Codes and Urban Livestock}

As with regulations of other land use activities, regulation of urban livestock is multilayered. As permitted under state enabling legislation, municipalities can use a variety of regulatory tools to guide social and economic activity in urban environments. Municipal codes usually incorporate zoning ordinances, animal control ordinances, and public health ordinances to provide guidance on whether, where, and how all sorts of animals, including livestock, can be kept in the city. 
In the case of urban livestock, planners and other officials were complicit in the exodus of animals from the city, utilizing municipal regulations to push agricultural activities beyond urban boundaries. Early on, the justification for moving animals out of the city was based largely on public health concerns, and thus the regulation of animalkeeping is often incorporated into municipal health codes. New York City serves as an instructive example. The city's groundbreaking Metropolitan Health Bill of 1866 established a regulatory framework for dealing with health and sanitation problems to enhance quality of life and prevent the spread of disease. In 1877 the city's relatively new Health Board banned chickens and other fowl due to public health concerns associated, at least in part, with poultry slaughtering. City dwellers had to obtain a special permit from the city's Health Department to set the conditions under which birds could be kept and killed in city limits (Orbach \& Sjoberg, 2011a). According to Orbach and Sjoberg (2011a), many cities followed suit and began to ban urban livestock of various types due to concerns over public health.

Over time, regulating urban livestock became more than just a question of public health. Urban dwellers began to view city life as distinct and separated from rural life (Blecha, 2007; Cronon, 1991; Gaynor, 1999, 2007; Schiere, Thys, Matthys, Rischkowsky, \& Schiere, 2006). Andrea Gaynor (2007, p. 29) pegs the decline of productive animal keeping in Australian cities on "an imaginative geography, in which productive animals were deemed inappropriate occupants of urban spaces." Instead, urban dwellers, particularly those of the middle and upper classes, began to prioritize "amenity, privacy, order, and the protection of real property values" (Gaynor, 2007, p. 29), a perspective which did not allow for animal keeping in urban and semi-urban areas. They effectively lobbied for local government regulations to support this agenda and urban dwellers in industrialized countries around the world came to support a perspective of a clean, orderly, and animal-free city (Blecha, 2007; Gaynor, 1999, 2007).
Traditional zoning practice effectively accomplished the desired separation. Zoning codes segregated rural from urban life, only minimally allowing urban agriculture activities (Pothukuchi \& Kaufman, 1999). These zoning restrictions relied on the segregation of uses modeled in Euclidean zoning, which seeks to ensure that the "right thing" does not end up in the "wrong place, such as a pig in the parlor instead of the barnyard" ("Village of Euclid v. Ambler Realty Co.," 1926). Generally prohibitive of many livestock activities or at a minimum relegating livestock to large lots on the periphery (Blecha, 2007; Gaynor, 1999, 2007), these new controls essentially banned all farming in towns and put it in the hands of those in the countryside (Steel, 2009).

\section{Bringing Livestock Back to the City}

Although raising productive animals in urban environments has been fraught with contradictions since the first cities were constructed, livestock has never been fully extirpated from cities. Since industrialization, much livestock keeping has been undertaken behind the scenes, quietly, invisibly (Gaynor, 1999). Immigrant populations have long brought their practices of livestock keeping and slaughtering to cities in the United States (Blecha, 2007; Schiere \& Hoek, 2001; Schiere et al., 2006). The urban poor and others who seek self-reliance have continuously kept some livestock in cities (Gaynor, 1999, 2007; Steel, 2009). And, during periods of societal transition such as economic depression or war, support for urban animal keeping reemerges and government programs and campaigns are launched to encourage urban farm activities (Blecha, 2007; Smit et al., 2001). The Depression of 1893, World Wars I and II, and the Great Depression each led to a short-term resurgence of livestock raising in and around cities in industrialized nations. Similarly, a resurgence of urban livestock often accompanies a coincident growth in other urban agricultural activities, such as urban gardening and community gardens. During World War II, for example, victory gardens were often accompanied by the raising of chickens, rabbits, and hogs to support the urban diet (Blecha, 2007). 
The most recent resurgence of support for urban livestock raising in industrialized nations has been linked to the local foods movement. Combining desires for healthier dietary practices, community sustainability and resilience, and greater access to safe and healthy food options, among others, a vibrant movement promoting local foods has grown in popularity and influence over the last decade and a half (Born \& Purcell, 2006; Campbell, 2004; Delind, 2011; Wekerle, 2004). The local foods movement in its various articulations has become a powerful advocating force to expand urban agriculture in cities throughout the country (Delind, 2011; Gaynor, 2007). Just as in previous eras when urban farming gained popularity, the new era is dominated by the production of fruits and vegetables in backyard and community gardens. However, urban livestock is also reemerging in earnest, with egg-laying hens and honey-making bees leading the way (Blecha, 2007; Orbach \& Sjoberg, 2011a; Salkin, 2011).

Despite ongoing debates about whether localizing the food system is either possible or desirable (Born \& Purcell, 2006; Glaeser, 2011), the push for locally produced or locally sourced foods has gained traction throughout the United States, leading to a rise in urban agriculture and related activities. Planners have found a new role to play in this emergent context. Instead of seeking ways to separate city life from rural life, they are increasingly drawn to incorporate urban agriculture, community gardens, and farmers' markets into comprehensive plans, zoning and subdivision ordinances, and urban revitalization efforts (Hodgson, et al., 2011). Farmers' markets are on the rise, increasing from under 2,000 markets in 1994 to more than 6,000 in 2010 (U.S. Department of Agriculture (USDA) Agricultural Marketing Service, 2011). Community supported agriculture, community gardens, school gardens, food cooperatives, community kitchens, and other urban agricultural activities to support local food systems are springing up throughout the country (Hodgson et al., 2011; Vallianatos, Gottlieb, \& Haase, 2004). Local governments, nonprofits, and voluntary associations have developed partnerships and programs to enhance gardening opportunities and to educate interested members of the public who want to get involved. Numerous U. S. cities have developed sustainability plans, comprehensive plans, and zoning ordinances to reflect policies related to food systems (Goldstein, Bellis, Morse, Myers, \& Ura, 2012; Hodgson, et al., 2011). Some cities, such as Minneapolis, Minnesota, have developed standalone urban agriculture plans to supplement their comprehensive land use plans (City of Minneapolis Community Planning and Economic Development Department, 2011).

Even with the building momentum toward locally produced or sourced foods and a revival of urban agriculture, raising livestock in urban and semiurban environments remains a thornier issue than urban gardens. Dominant perspectives about what it means to live in the city are not easily overturned. Although advocates argue that local food can promote public health and sustainability, the public health reasons that drove animals out in the first place have not been resolved. Concerns about disease and pestilence remain when livestock and people live in close proximity.

Municipal codes specifying regulations for urban livestock seek to mitigate the potential negative impacts of small-scale animal husbandry in urban and semi-urban areas by setting the conditions under which this practice can be undertaken. Over the last decade, numerous municipalities have reviewed and revised their ordinances as this issue has gained policy salience (Blecha, 2007; Gaynor, 1999; Goldstein et al. 2012; Hodgson et al., 2011; LaBadie, 2008; Orbach \& Sjoberg, 2011b; Salkin, 2011). Blecha (2007) and Gaynor (1999, 2007) provide useful theoretical interpretations about how changing livestock regulations have coincided with an emergent blurring of understandings and experiences of urban and rural life. The analyses by Salkin (2011) and Orbach and Sjoberg (2011a; 2011b) provide a strong foundation in legal trends associated with backyard chickens. To my knowledge there has been no similar analysis performed on ordinances addressing urban livestock beyond chickens. Hodgson et al. (2011) and Goldstein et al. (2012) offer excellent overviews of urban agriculture trends in general, although small scale 
urban livestock policies are only cursorily treated. While thousands of municipalities across the country have animal control ordinances, and many allowing urban livestock have been on the books for decades, a number of localities have taken up this issue in recent years to revise their ordinances, often at the behest of local food advocates (Orbach \& Sjoberg, 2011a; Salkin, 2011; Hodgson et al., 2011). A few have chosen to go against the tide and prohibit urban livestock activities (Salkin, 2011); however, an increasing number seek to balance the tension between calls for increased urban livestock husbandry and continued resistance to animals in the city. Through an analysis of municipal codes addressing urban livestock issues, this paper aims to provide guidance to planners and advocates as well as to chart a course for further research in this area as public officials face the thorny challenge of determining the extent to which and how to welcome livestock back into the city.

\section{Methods}

For this study, the author selected 22 U.S. municipalities that have recently revised their animal control ordinances and/or zoning codes to allow for urban livestock (see appendix for the list of localities and sources for ordinances included in the analysis). This sample includes municipalities that recently have taken up food systems planning issues in general and urban livestock in particular, as identified by stories in recent news media, legal studies of ordinances allowing backyard chickens (LaBadie, 2008; Orbach \& Sjoberg, 2011a; Salkin, 2011), and food systems planning literature, especially the urban agriculture edition of the American Planning Association's Planning Advisory Service (Hodgson, et al., 2011). The municipalities range from small towns such as South Portland, Maine, and Morgan Hill, California, with populations less than 40,000 , to large metropolitan centers such as Charlotte, North Carolina (population over $700,000)$ and San Antonio, Texas (population over 1.3 million). The sample was purposive to emphasize variability in terms of regional representation and population size as well as approaches to managing urban livestock. The study includes only municipalities that allow urban livestock activities to some extent, as the aim of this paper is to examine how cities navigate challenges associated with welcoming livestock back to urban areas through their municipal ordinances.

To analyze the ordinances, the author and his research assistants downloaded municipal codes available online and isolated sections of the code associated with livestock keeping. In general, livestock keeping is addressed in zoning, animal control, and public health sections of the codes. After collecting the codes, the author reviewed the pertinent sections of each ordinance for language related to the regulation of livestock keeping. The ordinance analysis required cross referencing between sections to interpret the intent of the code. In some cases, inconsistencies emerged between different sections of the code. When possible and applicable, we sought to double-check our interpretations of the code with local officials. However, there are grey areas in some of these codes, and enforcement of different sections is often the responsibility of different agencies. The results section points to some of these complexities of interpretation.

The research process incorporated a standard qualitative data analysis approach that begins by developing analytical categories. In this case, the categories aligned with a multilayered view of municipal regulations. At the broadest level, municipalities set limits on what livestock are allowable within their boundaries by prohibiting certain types outright. At the next level, localities designate certain uses as allowable in specified zones. Within those allowable zones, municipalities regulate at the site level, designating minimum lot sizes, setbacks, and number limits on the animals. And, in terms of individual practices, municipalities regulate various aspects of animal keeping, ranging from what types of accessory structures are allowed or required to where to keep animal feed and how animals are to be treated. Once these categories were defined, the analysis proceeded by linking ordinance sections to each category in the analytical framework and developing new codes and categories to sort and describe the data (Charmaz, 2006; Miles \& Huberman, 1994). 


\section{Results}

The analysis of municipal ordinances is divided into four sections. The first section, animal type prohibitions and nuisance conditions, specifies how localities prohibit certain animal types from municipal boundaries or clarify nuisance. The second section on district or zone limits explains how municipal codes address urban livestock through zoning and categorizes each locality based on how restrictive or permissible the zoning code is. The section on site-level restrictions examines how codes specify lot sizes, setbacks, and number of animals to regulate urban livestock keeping at the property level. The site-level analysis examines one of the more complex components of the codes as the specifications within these regulations tend to vary greatly across different municipalities and animal types. Therefore, the section includes a synthesis analysis across the municipalities using one animal type (chickens) as an example. Finally, the section on regulating livestock-keeping practices examines how the codes regulate individual practices by establishing permitting requirements, technical specifications, and administrative oversight.

\section{Animal Type Probibitions and Nuisance Conditions} People live in close proximity in urban areas, so in order to protect public health, safety, and welfare, municipalities can choose to prohibit certain uses outright. In the case of animal husbandry, the issues of nuisance related to odor, noise, pestilence, and waste as well as associated public health impacts are the primary concerns that lead to animals being prohibited from urbanized areas. Not all animals pose a significant risk to health or nuisance, but those animals that are identified as particularly problematic can be prohibited.

Most likely due to the high potential for noise nuisance, few communities allow roosters without significant restrictions. Eight of the municipalities included in this study prohibit roosters outright: Seattle, Washington; Fort Collins, Colorado; Bloomington, Indiana; Baltimore, Maryland; Mobile, Alabama; Ann Arbor, Michigan; Rogers, Arkansas; and South Portland, Maine (see table 1). In other localities, roosters are allowed under limited conditions. Many localities allow roosters only in agricultural or large lot residential zones, or have stringent setbacks of 100 feet (30 meters) or more from neighboring residences or property lines. Others specify conditions which would constitute a nuisance. For example, Cleveland, Ohio, allows roosters, but the code specifies that "it shall be unlawful for any person or other party operating or occupying any building or premises to keep or allow to be kept any animal or bird that makes noise so as to habitually disturb the peace and quiet of any person in the vicinity of the premises." Similarly, Stamford, Connecticut, allows roosters but specifies that "no person shall keep any rooster in such location that the crowing thereof shall be annoying to any person occupying premises in the vicinity. Upon complaint of any such person so annoyed, the Director of Health shall have authority to order the owner of such rooster to remove the same so that such annoyance shall cease." Although not summarily prohibited, these codes specify that it is the owner's responsibility to avoid noise nuisance issues.

Many codes specify types of prohibited animals beyond roosters. Some narrowly specify certain types, such as Cleveland, Ohio, where the only animals prohibited outright are Africanized bees; Chattanooga, Tennessee, where the code prohibits peacocks; or San Antonio, Texas, which does not allow swine. Along with roosters, Seattle does not allow swine except for miniature potbelly pigs. Others have broader prohibitions. Ann Arbor does not allow domestic fowl other than chickens. The Baltimore health code lists 19 categories of prohibited animals including all bovine (cattle), porcine (pigs) except Vietnamese potbellied pigs, even-toed ungulates (sheep, goats, etc.), and odd-toed ungulates except for domesticated horses in the arabber ${ }^{2}$ and carriage trades. In the end, the only allowable animal types for food production purposes in Baltimore are chicken hens and bees. All others are banned.

\footnotetext{
2 An arabber is "a street merchant_who sells fruits and vegetables from a colorful, horse-drawn cart" (http://en.wikipedia.org/wiki/Arabber)
} 
Table 1. Livestock Type Prohibitions in Sample

( $\mathrm{P}=$ prohibited, $\mathrm{A}=$ allowable, $\mathrm{S}=$ some in category allowed, blank=none specified or unclear)

\begin{tabular}{|c|c|c|c|c|c|c|c|c|c|}
\hline Municipality & State & Population & Chickens & Roosters & $\begin{array}{l}\text { Other } \\
\text { fowl* }\end{array}$ & $\begin{array}{l}\text { Honey } \\
\text { bees }\end{array}$ & $\begin{array}{c}\text { Small } \\
\text { animals* }\end{array}$ & $\begin{array}{l}\text { Medium } \\
\text { animals* }\end{array}$ & $\begin{array}{c}\text { Large } \\
\text { animals* }\end{array}$ \\
\hline Ann Arbor & Michigan & 112,920 & $A$ & $P$ & $\mathrm{P}$ & A & A & $P$ & $\mathrm{P}$ \\
\hline Baltimore & Maryland & 637,418 & $A$ & $P$ & $P$ & $A$ & $P$ & $\mathrm{P}$ & $P$ \\
\hline Bloomington & Indiana & 71,939 & A & $\mathrm{P}$ & A & & A & A & A \\
\hline Charlotte & North Carolina & 704,422 & A & A & A & A & A & A & A \\
\hline Chattanooga & Tennessee & 171,350 & A & $A$ & $A$ & A & $A$ & $A$ & A \\
\hline Cleveland & Ohio & 431,369 & $A$ & $A$ & $A$ & $A$ & $A$ & $A$ & $A$ \\
\hline Fort Collins & Colorado & 138,733 & $A$ & $P$ & & $A$ & & & \\
\hline Kansas City & Missouri & 482,299 & $A$ & $A$ & $A$ & $A$ & $A$ & $A$ & $A$ \\
\hline Longmont & Colorado & 88,425 & $\mathrm{~A}$ & $\mathrm{~A}$ & $\mathrm{~A}$ & $\mathrm{~A}$ & $\mathrm{~A}$ & $\mathrm{~A}$ & $\mathrm{~A}$ \\
\hline Madison & Wisconsin & 235,419 & A & A & A & & A & $\mathrm{S}$ & A \\
\hline Missoula & Montana & 68,876 & A & $A$ & $A$ & $A$ & $A$ & $A$ & $A$ \\
\hline Mobile & Alabama & 193,205 & $\mathrm{~A}$ & $\mathrm{P}$ & $\mathrm{A}$ & & & $\mathrm{S}$ & $\mathrm{A}$ \\
\hline Morgan Hill & California & 38,547 & $\mathrm{~A}$ & & A & A & $\mathrm{A}$ & $\mathrm{A}$ & $A$ \\
\hline Mountain View & California & 72,222 & A & A & A & & A & $A$ & A \\
\hline Rogers & Arkansas & 59,017 & A & $\mathrm{P}$ & A & & $\mathrm{A}$ & $\mathrm{S}$ & $\mathrm{A}$ \\
\hline Round Rock & Texas & 105,424 & A & & $\mathrm{A}$ & & A & $\mathrm{A}$ & A \\
\hline San Antonio & Texas & $1,373,668$ & $A$ & & $A$ & & $A$ & $\mathrm{~S}$ & $A$ \\
\hline Santa Clara & California & 111,997 & $\mathrm{~A}$ & $\mathrm{~A}$ & $\mathrm{~A}$ & & $\mathrm{~A}$ & $\mathrm{~A}$ & $\mathrm{~A}$ \\
\hline Seattle & Washington & 608,660 & $A$ & $\mathrm{P}$ & A & $A$ & $A$ & $\mathrm{~S}$ & $A$ \\
\hline South Portland & Maine & 23,976 & $\mathrm{~A}$ & $\mathrm{P}$ & & $A$ & & & \\
\hline Stamford & Connecticut & 121,026 & A & $\mathrm{A}$ & A & & A & A & A \\
\hline Tallahassee & Florida & 172,574 & $A$ & $A$ & $A$ & & $P$ & $P$ & $\mathrm{~S}$ \\
\hline
\end{tabular}

* Other fowl includes turkey, geese, ducks, etc. Small animals include rabbits. Medium animals include goats, pigs, sheep, etc. Large animals include cows, horses, alpacas, llamas, etc.

Table 1 provides a summary across all municipalities on the question of animal type prohibitions. Among the municipalities in this study, prohibiting certain livestock outright is used by around half of the ordinances. However, all of the ordinances allow chickens and a great majority allows other fowl, small, medium, and large animals at least somewhere within municipal boundaries. In the end, prohibiting animals outright is used rather minimally by these localities.

\section{District or Zone Limits}

Many localities use zoning regulations to restrict or permit where in the urban environment livestock can be raised. Most localities specify where agri- cultural uses are allowable within their zoning regulations. In a few cases, the animal control ordinance clarifies zones in which livestock animals can be kept. Tentative efforts have been made in some cities where nearly all livestock keeping is allowable only in agricultural zones. Other local governments have more permissible zoning regulations, allowing most types of livestock in almost all residential zones, subject to specific site-level restrictions. Between these two extremes are municipalities that allow urban livestock in certain residential zones either as an outright use or as an accessory or conditional use. The analysis categorizes zone or district limits as highly limited (livestock in agriculture zones only with the exception of chickens and 
bees), moderately limited (includes allowing small animals or other fowl in residential zones), and widely permitted (some medium and/or large animals allowable in residential zones) (see table 2).

\section{Highly limited}

Most communities still maintain highly restrictive zoning for urban livestock. The municipalities in this category limit livestock keeping to agricultural zones with the exception of chickens and/or bees, which are permissible in residential zones. Cities in this category include Longmont, Mobile, Rogers, Santa Clara, and Ann Arbor, among others (see table 2). In the end, over half (12) of the municipalities in this study have zoning restrictions that limit livestock except chickens and/or bees to agricultural zones.

In some of these localities, the zoning code limits all livestock keeping to nonresidential zones. Santa Clara only allows livestock keeping in agricultural zones. San Antonio allows small produce farms in residential areas, but only allows livestock in the Mixed Light Industrial or Farm and Ranch zones. In most cases, communities continue to limit livestock keeping to agricultural zones with the exception of chickens or bees which are allowed in some residential districts. Mobile's city code permits the keeping of all livestock in Residential Agricultural zoning districts, which are sparsely populated single-family residential areas of the city. The city code also permits livestock feedlots and wholesale operations in the highly intensive industrial zone. Livestock keeping in all other parts of the city is prohibited, with the exception of chickens. For chickens, the code specifies that up to 25 chickens can be kept in all residential zones. Longmont and Fort Collins allow chicken hens in all residential zones, but other livestock are relegated to agricultural zones in these cities. Ann Arbor allows chickens and bees in low-density residential areas where the use on site is either single- or two-family dwellings. Madison allows the keeping of up to four chickens in medium and low density residential zones, but other livestock keeping is relegated to agricultural zones. Rogers allows up to four chicken hens at single-family residences in all zones, but no other livestock outside the agricul- tural zone. The proposed zoning code draft for Baltimore allows urban livestock as a conditional use in most residential districts, several commercial zones, and office residential zones as long as there is a management plan for minimizing the risk of nuisance conflicts. However, as in the case of Ann Arbor, only chickens and bees are allowed in the animal control ordinance.

\section{Moderately limited}

Municipalities with moderately limited zoning restrictions for livestock keeping include those that allow small animals and/or other fowl as well as chickens and bees in some residential areas, but relegate most medium and all large animals to agricultural zones. Mountain View, Morgan Hill, Cleveland, Chattanooga, and Round Rock fall into this category.

In Morgan Hill, small animals and chickens are allowable in most residential zones. Other livestock, up to two large and four medium animals on the first 40,000 square feet (3,700 square meters), may be kept in residential estate zones with the exception of swine and bees, which are confined to agricultural zones. Cleveland allows fowl, small animals, and some medium animals such as goats in residential districts, subject to certain conditions. However, larger animals are relegated to agricultural zones. Mountain View allows up to four small animals, including chickens, rabbits, geese, ducks, and other fowl in all residential zones. Round Rock allows livestock raising in Agricultural zones and the Single Family Rural zone, which has a minimum lot size of 2 acres ( 0.8 hectare). The animal control ordinance further specifies the requirements (such as a minimum lot size of 1 acre or 0.4 hectare) necessary for animals to be kept within city limits that are not in those two zoning districts. Chattanooga established a new urban agriculture zoning district (A-1) in city limits with code revisions in 2001. The code only allows urban livestock to be kept on lots of 20 or more acres ( 8 or more hectares) in this zone unless the agricultural use is incorporated into a Planned Unit Development. According to Chapter 7 of the municipal code revised in January, 2008, however, fowl, swine, goats, and chickens (including roosters) can be kept 
in all other zones of the city as long as lot sizes are at least 5 acres ( 2 hectares). Thus, while the lot size limitations are stringent, the actual zones in which animals can be kept are only moderately limited given that some medium-sized animals can be kept in all zones.

\section{Widely permitted}

In some municipalities, zoning regulations do not significantly limit where urban livestock keeping takes place. Ordinances that are within this category allow most animal types, including some large animal livestock, in residential areas as well as other zones within the municipality. Kansas City, Seattle, Stamford, Missoula and Charlotte fall into this category. Seattle permits outright "the keeping of small animals, farm animals, domestic fowl and bees...in all zones as an accessory use to any principal use..." Missoula limits livestock keeping to residential zones that have minimum lot sizes of 1 acre, but the city allows all types of animals in those zones. Chickens can be kept in all residential zones regardless of lot size. In Kansas City there are no district limits for animal husbandry activities. Similarly, in Stamford, farm uses are widely permitted and allowable in all districts as an incidental and auxiliary use. In residential districts in particular, the code allows "the keeping of livestock incidental to the domestic establishment of a residential use of the parcel of land on which such livestock are kept." In Charlotte, farms and all farming activities allowable elsewhere in the code are permitted outright in all zoning districts. Table 2

categorizes each city on the scale of district or zone limits.

\section{Site-Level Restrictions}

At the site level, regulations for urban livestock vary and include lot size, setbacks, and number of

\section{Table 2. District or Zone Limits}

\begin{tabular}{|c|c|c|c|c|}
\hline Municipality & State & Highly limited & $\begin{array}{l}\text { Moderately } \\
\text { limited }\end{array}$ & $\begin{array}{c}\text { Widely } \\
\text { permitted }\end{array}$ \\
\hline Ann Arbor & Michigan & $x$ & & \\
\hline Baltimore & Maryland & $x$ & & \\
\hline Bloomington & Indiana & $x$ & & \\
\hline Charlotte & $\begin{array}{l}\text { North } \\
\text { Carolina }\end{array}$ & & & $x$ \\
\hline Chattanooga & Tennessee & & $x$ & \\
\hline Cleveland & Ohio & & $x$ & \\
\hline Fort Collins & Colorado & $x$ & & \\
\hline Kansas City & Missouri & & & $x$ \\
\hline Longmont & Colorado & $x$ & & \\
\hline Madison & Wisconsin & $x$ & & \\
\hline Missoula & Montana & & & $x$ \\
\hline Mobile & Alabama & $x$ & & \\
\hline Morgan Hill & California & & $x$ & \\
\hline Mountain View & California & & $x$ & \\
\hline Rogers & Arkansas & $x$ & & \\
\hline Round Rock & Texas & & $x$ & \\
\hline San Antonio & Texas & $x$ & & \\
\hline Santa Clara & California & $x$ & & \\
\hline Seattle & Washington & & & $x$ \\
\hline South Portland & Maine & $x$ & & \\
\hline Stamford & Connecticut & & & $x$ \\
\hline Tallahassee & Florida & $x$ & & \\
\hline
\end{tabular}

animals. Most ordinances use a graduated approach to clarify lot size and setback restrictions based on animal type or numbers. In short, larger animals tend to require larger lot sizes and more extensive setback requirements. Numbers limits tend to be higher for smaller animals and more stringent for larger animals. However, there is great variability across municipalities. This section outlines some of the key characteristics of site-level restrictions in these three categories and then provides a summary analysis across the municipalities using chickens as the example.

Lot sizes

A few municipalities set overall minimum lot sizes before the keeping of livestock is an allowable use. Chattanooga, for example, sets an overall minimum 
for swine, goats, chickens and roosters, which can only be kept in city limits on lots that are 5 contiguous acres ( 2 hectares) in size. Others tend to use a graduated approach and set lot size requirements based on the relative space requirements of each animal type. Seattle serves as an instructive example. Three small animals are permitted as "accessory to each business establishment...or dwelling unit on a lot." Up to eight domestic fowl can be kept in addition to small animals on any lot. Four small animals can be kept on lots of at least 20,000 square feet (1,860 meters) with single-family homes. The code permits one additional small animal on single family residential lots "for each 5,000 square feet [460 square meters] in excess of 20,000 square feet [1,860 square meters].” Larger animals (e.g. cows, horses, and sheep) can only be kept on lots larger than 20,000 square feet $(1,860$ square meters) but residents can keep one such animal per 10,000 square feet (930 square meters) on the lot. Cleveland also uses the graduated approach and specifies minimum lot sizes for medium-sized animals at 14,400 square feet $(1,340$ square meters) (about one-quarter acre or 0.1 hectare) in nonresidential areas and 24,000 square feet (2,230 square meters) (a little more than half an acre or 0.2 hectare) in residential areas. Small animals including chickens, geese and ducks require a minimum lot size of 800 square feet (74 square meters) in residential areas.

Other codes specify fewer categories but still use a graduated approach. In Bloomington, a minimum lot size of 5 acres ( 2 hectares) or 300 feet (91 meters) of width is required to keep large animals, while chickens can be kept on lots of two or more acres ( 0.8 hectare). Tallahassee requires 5 contiguous acres ( 2 hectares) for horses and fowl (besides chickens) and 15 acres (6 hectares) for all other livestock in the city. In Round Rock, minimum lot size is set at 1 acre ( 0.4 hectare) for all medium and large livestock types, but no lot size restrictions are placed on the keeping of fowl.

Either in conjunction with or in lieu of overall lot size, some municipalities regulate the size of land for the animal's use, which effectively sets minimum lot size requirements. Missoula requires a half acre ( 0.2 hectare) of land for the animal's sole use for medium and large animals. Similarly, Chattanooga requires one-quarter acre ( 0.1 hectare) of pasturage for small and medium animals and 1 acre (0.4 hectare) of pasturage for each large animal. San Antonio requires a minimum of 400 square feet (37 square meters) of pen for each bovine or equine species and 200 square feet (19 square meters) for each goat or sheep. Bloomington limits livestock to one animal unit per acre ( 0.4 hectare) of land used as pasture with large animals counting as one unit, medium animals as 0.5 units and fowl as 0.2 units. Charlotte requires a minimum of 2 acres $(0.8$ hectare) of pasturage for cows and other large livestock excluding horses and one-quarter acre $(0.1$ hectare) for each goat, sheep, or other medium sized livestock.

\section{Setbacks}

Used alternatively or in conjunction with lot sizes, setbacks ensure a minimum distance from neighboring property lines or structures. The use of setbacks is particularly prevalent in animal control ordinances in relation to residential properties and structures. Many municipalities use setbacks as a central tool to separate nearby residences from animals that might cause nuisance.

Where not prohibited, roosters tend to have strict setbacks. Santa Clara specifies that "no person shall keep any rooster which crows, or is capable of crowing within one hundred (100) feet [30 meters] of any dwelling unit other than the dwelling unit of the person owning or in possession of such rooster, unless proof is presented to the housing coordinator that successful treatment to prevent crowing has been performed." Cleveland also uses 100 feet (30 meter) setbacks for coops and enclosures that house roosters.

Beyond roosters, setbacks tend to be relatively strict for large animals and less stringent for chickens and small animals. Mountain View requires setbacks of 25 feet ( 8 meters) from neighboring residences for fowl and 200 feet (61 meters) for other livestock. In Round Rock, fowl must be enclosed and kept at least 25 feet (8 meters) away from neighboring residences. If more than 50 feet 
(16 meters) away, the allowable number of birds doubles from five to 10 . For other livestock, setbacks from neighboring residences must be 50 feet (16 meters) for grazing and 150 feet (46 meters) for enclosures. In Kansas City, livestock must be kept at least 200 feet (61 meters) away from any building used by humans other than the owner, and small animals must be kept at least 100 feet (30 meters) from such buildings and 25 feet (8 meters) from the property line. San Antonio requires livestock to be enclosed at least 100 feet (30 meters) from any dwelling or business other than the owner's. Chickens must be kept 25 feet (8 meters) from neighboring residences in Baltimore, 10 feet (3 meters) from the property line and 40 feet (12 meters) from residences in Ann Arbor, and 20 feet (6 meters) from neighboring dwellings in Tallahassee.

\section{Number of animals}

Some municipalities also limit the total number of animals allowed on each parcel. Ann Arbor only allows four chickens and two hives of bees per property owner. Baltimore allows no more than four chickens and 125 pigeons. The Kansas City ordinance limits adult chickens and other domestic fowl to 15, adult rabbits to 10, and larger livestock animals to two. Missoula and South Portland allow six chickens in residential areas, while Madison and Rogers allow four.

Many municipalities have graduated limits of numbers of animals tied to lot sizes and setbacks. For example, Fort Collins limits the number of beehives to two on lots that are less than one-quarter acre $(0.1$ hectare) in size and gradually increases the number to eight hives on one acre ( 0.4 hectare). There are no limits to the number of hives wherever the apiary can be situated 200 feet (61 meters) in any direction from all property lines (effectively setting a minimum lot size of about three acres or 1.2 hectares). Seattle allows up to three small animals and eight domestic fowl on all lots, but allows more animals and larger animals on lot sizes larger than a half acre ( 0.2 hectare). For medium and large animals, Missoula specifies allowable numbers per acre with maximum numbers set at three horses, mules, goats or donkeys; five sheep; or two cows or llamas. The Round Rock code states that "no more than one unit of livestock [can be kept] for the first acre [0.4 hectare] of land" with an additional unit for each additional half acre $(0.2$ hectare). Some livestock are equivalent to one unit, such as bovine and equine species. Swine are considered half units. Sheep, goats, and emus, among others, are considered one-fifth units.

\section{Site-level restriction synthesis}

One of the more popular animals for the urban environment is the chicken. Public pressure in support of backyard chickens has led many municipalities to develop ordinances to accommodate demand or deal with conflicts associated with chicken keeping (Blecha, 2007; LaBadie, 2008; Orbach \& Sjoberg, 2011a, 2011b; Salkin, 2011). For this reason, and because all of the municipal ordinances in this study addressed chickens, the analysis of how the codes treat chickens provides a sense of how different municipalities use site-level restrictions to regulate urban livestock.

In regulating backyard chickens, municipalities rely almost exclusively on setbacks and number limitations. Setbacks pertain to enclosures required to keep chickens and are established based on distance from property lines or neighboring residences or both. In some cases, setback restrictions can be relaxed with notification and approval of neighboring landowners. Number limits frequently establish a maximum allowance for hen keeping. However, in some cases, number limits are graduated based on lot sizes - the larger the lot, the more chickens the landowner can keep. Only two of the municipalities in this study, Chattanooga (5 acres or 2 hectares) and Bloomington (2 acres or 0.8 hectare), identified minimum lot size restrictions for chickens. The other localities either had no lot size restrictions or implied lot sizes based on zoning district limitations. Table 3 (next page) provides data on setbacks and number limitations for each municipality in the study.

As the table reveals, all of the municipalities manage urban chickens with one or more site-level tools. Depending on lot size, more than half of the municipalities have set limits of fewer than eight 
chickens and only four localities do not use number limits to regulate chickens. Eighteen of the 22 municipalities ensure that there is relatively substantial separation from the chickens and neighbors, establishing setbacks of at least 20 feet $(6$ meters) from neighboring residences. This table maps reasonably well onto other animal types in that municipalities tend to use at least one site-level restriction to control where urban livestock can be kept on individual parcels within allowable zones. One distinction is that lot sizes are more frequently used for medium and large sized animals in conjunction with setbacks and number limitations than for chickens. In general, the larger the animal, the more restrictive the number limits, the larger the lot size requirements, and/or the more expansive the setbacks.

\section{Regulating the Practice of Livestock Keeping}

To regulate livestock keeping practices, municipalities tend to specify conditions under which livestock can be husbanded under the public health or animal control chapters of municipal codes. These regulations generally describe how animals are to be treated, outline specifications of enclosures and confinements, identify agency or organizational oversight for inspections, and list other procedural and technical conditions that must be met before livestock keeping is allowed in specified areas of each locality. In many cases, localities also describe a process through which a permit can be obtained, along with associated fees.

\section{Permitting}

Most of the localities in this study utilize permitting or licensing programs to ensure that the specifica-

\section{Table 3. Site-Level Restrictions (Chickens Only)}

\begin{tabular}{|c|c|c|c|c|}
\hline Municipality & State & Property line setback & $\begin{array}{c}\text { Neighboring residence } \\
\text { setback }\end{array}$ & Number limit \\
\hline Ann Arbor & Michigan & $10 \mathrm{ft}(3 \mathrm{~m})$ & $40 \mathrm{ft}(12 \mathrm{~m})$ & 4 \\
\hline Baltimore & Maryland & & $25 \mathrm{ft}(8 \mathrm{~m})$ & 4 \\
\hline Bloomington & Indiana & & $20 \mathrm{ft}(6 \mathrm{~m})$ & 5/acre \\
\hline Charlotte & North Carolina & $25 \mathrm{ft}(8 \mathrm{~m})$ & & $20 /$ acre \\
\hline Chattanooga & Tennessee & $25-150 \mathrm{ft}(8-46 \mathrm{~m})$ & & $20 /$ acre \\
\hline Cleveland & Ohio & $5 \mathrm{ft}(1.5 \mathrm{~m})$ & & $1 / 800 \mathrm{ft}^{2}$ \\
\hline Fort Collins & Colorado & $15 \mathrm{ft}(4.5 \mathrm{~m})$ & & 6 \\
\hline Kansas City & Missouri & $25 \mathrm{ft}(8 \mathrm{~m})$ & & 15 \\
\hline Longmont & Colorado & $6 \mathrm{ft}(2 \mathrm{~m})$ & $6 \mathrm{ft}(2 \mathrm{~m})$ & 4 \\
\hline Madison & Wisconsin & & $25 \mathrm{ft}(8 \mathrm{~m})$ & 4 \\
\hline Missoula & Montana & & $20 \mathrm{ft}(6 \mathrm{~m})$ & 6 \\
\hline Mobile & Alabama & $20 \mathrm{ft}(6 \mathrm{~m})$ & $40 \mathrm{ft}(12 \mathrm{~m})$ & 25 \\
\hline Morgan Hill & California & $5 \mathrm{ft}(1.5 \mathrm{~m})$ & $20 \mathrm{ft}(6 \mathrm{~m})$ & $\mathrm{n} / \mathrm{a}$ \\
\hline Mountain View & California & & $25 \mathrm{ft}(8 \mathrm{~m})$ & 4 \\
\hline Rogers & Arkansas & & $25 \mathrm{ft}(8 \mathrm{~m})$ & 4 \\
\hline Round Rock & Texas & & $25-50 \mathrm{ft}(8-15 \mathrm{~m})$ & $5-10$ \\
\hline San Antonio & Texas & & $100 \mathrm{ft}(30 \mathrm{~m})$ & 3 \\
\hline Santa Clara & California & & $50 \mathrm{ft}(15 \mathrm{~m})$ & $\mathrm{n} / \mathrm{a}$ \\
\hline Seattle & Washington & & $10 \mathrm{ft}(3 \mathrm{~m})$ & $8+$ \\
\hline South Portland & Maine & $20 \mathrm{ft}(6 \mathrm{~m})$ & & 6 \\
\hline Stamford & Connecticut & $50 \mathrm{ft}(15 \mathrm{~m})$ & & $\mathrm{n} / \mathrm{a}$ \\
\hline Tallahassee & Florida & & $20 \mathrm{ft}(6 \mathrm{~m})$ & $n / a$ \\
\hline
\end{tabular}


tions for livestock keeping practice will be met prior to a landowner engaging in animal husbandry. Only two cities, Chattanooga ${ }^{3}$ and Round Rock, did not specify a permitting program for livestock animals in their ordinances. In these cities, the requirements for livestock keeping are as specific as in most other municipalities, and livestock keepers are just as subject to inspections as their counterparts in other cities. The major difference is that livestock keepers do not have to obtain a permit prior to engaging in the practice. All other localities in this study used some sort of permitting process for at least one, if not all, allowable animal types. In essence, to receive a permit, the applicant must demonstrate, either through a paper application or a property inspection, that he or she will be able to meet the specifications for livestock keeping outlined in the code. In some cases, such as in Bloomington and Ann Arbor, permits will be granted only after a waiver is obtained from all adjacent property owners indicating that they do not object to the keeping of the animals.

\section{Management specifications}

Seventeen of the 22 animal control ordinances reviewed in this study provided specific guidelines for animal husbandry practices in order to receive a permit or to engage in the practice if a permit is not required. Guidelines clarify whether or not an enclosure is required, the design specifications for the enclosure, and setback requirements from neighboring properties as well as the owner's residence. They also tend to outline cleaning requirements, including the frequency and acceptable techniques for cleaning enclosures and disposing of animal wastes. There are usually care requirements, such as ensuring that there is adequate water, food, and space for each animal. There is a wide range of variability in the specifics, but in general, these provisions outline standards for the treatment and care of animals and ways to reduce potential public health concerns or nuisances.

\footnotetext{
${ }^{3}$ The Chattanooga code does require a permit for keeping goats to use for kudzu control. However, the purpose of keeping the animals is not to yield agricultural outputs.
}

The animal control ordinance in Missoula serves as an example of the types of requirements owners must adhere to in order to receive a permit and to avoid being in violation of the code. For animals kept on one acre ( 0.4 hectare) of property or more, there are few restrictions. For chicken hens kept in residential zones, the animals must be kept in a "covered, predator-proof chicken house that is thoroughly ventilated, of sufficient size to admit free movement of the chickens, designed to be easily accessed, cleaned and maintained by the owners and be at least 2 square feet $[0.2$ square meter] per chicken in size." The chicken coop must be 20 feet (6 meters) away from neighboring residences. The birds have to be shut into the chicken house from sunset to sunrise and fenced in a predator-proof enclosure during daylight hours. Feed has to be stored in containers that can be kept free of rodents and predators. And, even after all of these conditions are met, "it is unlawful for the owner, custodian, or keeper of any chicken to allow the animal(s) to be a nuisance to any neighbors." Animal control officers determine nuisance violations on a case-by-case basis.

Charlotte serves as another example. For domestic fowl and rabbits, Charlotte's code requires that the animals be enclosed in a well ventilated structure of at least 18 inches $(0.5$ meter) in height that provides 4 square feet ( 0.4 square meter) of space for each bird or rabbit. It also specifies that "the coop, fowl house or hutch shall be kept clean, sanitary and free from accumulation of animal excrement and objectionable odors. It shall be cleaned daily, and all droppings and body excretion shall be placed in a flyproof container and double-bagged in plastic bags." It limits the number of animals to 20 per maintained acre ( 0.4 hectare) and specifies setbacks of 25 feet ( 8 meters) from property lines. For larger livestock animals, the code requires sheltered enclosures "adequate...to protect them from the elements" which are kept clean and sanitary and set back from property lines 25 to 75 feet ( 8 to 23 meters), depending upon the animal size.

The remaining five municipalities in this study (Baltimore, Cleveland, Madison, Stamford, and Morgan Hill) demur on this level of specificity. 
Instead, they provide a level of administrative discretion to determine whether the proposed use is appropriate to the specific conditions of the site. In Baltimore, for example, the proposed revision of the zoning code specifies that landowners wishing to engage in animal husbandry and other intensive agricultural activities "must prepare a management plan that addresses how the activities will be managed to avoid impacts on surrounding land uses and natural systems." In Stamford landowners are required to keep animal enclosures in a "reasonably clean and sanitary condition," while the director of health can order the owner to clean the enclosure when "in his judgment conditions therein are unsanitary." In Morgan Hill the code specifies that the location of enclosures for livestock will be reviewed and approved based on criteria including "type and size of animals, existing land use and structures on site, adjacent land uses and structures, possibility of noise and odor impacts on neighbors, topography, relationship to streets and alleys, applicable fence location and height regulations, and protection of fences between the property and adjacent lots." The language in these codes provides administrative discretion to the officers charged with enforcing the code while also providing a level of flexibility to landowners to come up with ways to minimize nuisance or public health concerns.

\section{Administrative oversight}

Many ordinances specify administrative oversight to manage the permitting program and to conduct inspections to identify code violations. Municipalities rely on a variety of departments such as those responsible for health, animal control, land development and building, or their equivalents to administer the permitting program. In general, codes clarify that a permit will be issued once the administrative department has ensured that all the provisions of the code have been met by the applicant.

In many cases, public health officers administer the program. For example, the Mobile code states that "it shall be unlawful for any person to keep or maintain any chickens within the city without first obtaining a permit from the health officer. The health officer shall issue a permit when there has been full compliance with the provisions of this division [of the code]." Anyone proposing to keep farm animals or bees in Cleveland must apply to the department of health for a license that must be renewed every two years. The application includes property specifications, number and types of animals, site plans, a feces removal plan, and neighbor addresses. Once the director of public health determines that nuisances will be mitigated and neighbor concerns are addressed, the application is approved and submitted to the building department for final review. In the case of Cleveland, involving the health department in code enforcement and development may have facilitated the passage of the ordinances allowing urban livestock. When urban agriculture advocates and the city planning staff began drafting ordinance language for urban livestock keeping, they worked with the city's department of public health to address health risks and nuisances. The involvement of the department "eased public and political concern about potential nuisance issues and contributed to quick approval... by city council” (Hodgson et al., 2011, p. 76).

In many municipalities, several public officers can serve as inspectors. For example, in Missoula the health officer, animal control officer, or city police department can be involved in inspections to ensure that enclosures are kept clean. If not clean, the health officer can submit that the conditions warrant a public health nuisance and the owner either has to comply with the code or suspend the use. Meantime, animal control officers determine whether noise or smells constitute a nuisance, and police officers can enforce any aspect of the code. Similarly, South Portland relies on a variety of officials for enforcement. For example, once bee keeping is permitted, the code specifies that "the City Health Officer, the Animal Control Officer, the Code Enforcement Officer and/or the State Bee Inspector shall have the right to inspect any apiary. Where practicable, prior notice shall be given to the beekeeper."

In some cases, state agricultural department officials are notified and often provide licenses or 
permits for certain animal types. For example, the Seattle and South Portland codes require bees to be registered with the respective state departments of agriculture. In Baltimore, chickens must be registered with the Maryland Department of Agriculture, Domestic Poultry and Exotic Bird Registration Division.

In one outlier, the Fort Collins code relies on a nongovernmental organization to manage training and permitting. The ordinance specifies that "any person keeping chicken hens pursuant to this provision must first have been issued a permit by the Larimer Humane Society and have received such information or training pertaining to the keeping of chicken hens as the director of said agency deems appropriate." This is a particularly interesting example, as a regulatory function is handled by a private entity rather than public officials.

\section{Discussion and Implications}

Local governments throughout the United States are facing increasing pressure to incorporate food system issues into their planning and policymaking. The questions of whether and how to allow urban livestock keeping have risen alongside this emergent focus on food systems planning and the call for local food. This turn toward urban livestock is fraught with tensions. On the one hand, a common understanding of urban and rural divisions is being called into question. Farmers may no longer be relegated only to the hinterlands, as many urban residents are taking up various agricultural activities and choosing to label themselves "urban farmers" (Carpenter, 2009). Secondly, in an ironic twist, part of the motivation for bringing livestock back to the city is grounded in a public health argument. The rise of diabetes and an obesity epidemic have served as fruitful fodder for local food advocates, who argue that healthier eating can be promoted alongside urban agriculture activities that include raising livestock. And yet the primary reason that livestock were expelled from cities more than a century ago was likewise grounded in a public health argument. Navigating these two tensions and the social conflicts that can ensue is one of the core challenges that planners and public officials face as they incorporate food systems planning into their practice. Municipal officials have turned to traditional means to regulate urban livestock, allowing the return of animals to urban environments in deference to local food, sustainability, and other advocates, while maintaining restrictions on what types, where, and how such livestock can be raised within city limits.

\section{Regulating the Urban-Rural Divide}

Traditional land use codes separate uses, segregating homes from workplaces, urban activities from rural, and industries from shopping centers. Over the last century and a half, many urbanized municipalities sought to prohibit livestock keeping or at least to confine livestock to large-lot agricultural zones. In many of the municipal codes analyzed here, the lines are beginning to blur. More cities are beginning to allow livestock keeping in more densely urbanized areas.

One can think of this regulatory framework as a series of layers through which localities define the extent to which and how urban livestock keeping can be undertaken within municipal boundaries. The first layer operates at the level of the municipal boundary itself. Some animals are summarily prohibited. The second layer sorts animals into allowable zones, designating in what sections of the city the permissible animals can be kept. The next layer, those regulating site-level restrictions, delineate which parcels (lot size restrictions), where on a particular parcel (setbacks), and at what level of intensity (number limits) within the allowable zones livestock keeping can be undertaken. The final layer specifies how to engage in responsible livestock keeping practices by outlining requirements for the treatment, care, maintenance, accessory structures, confinement, and minimum space for each animal. This layer also outlines the responsible parties for permitting, oversight, and enforcement of the code.

These approaches to regulating land uses in the urbanized environment are not new. They are modeled on Euclidean zoning and putting "right things" in their "right places" and specifying how to conduct activities on the land that have minimal negative impacts on the users of neighboring prop- 
erties. What appears to be changing, at least at the margins, is our understanding of what "right things" and "right places" might be. All of the localities in this analysis are opening their boundaries to urban livestock to a certain extent, most are allowing some livestock keeping in residential areas, and a few are allowing some animals in relatively densely populated sections of the urban environment. This regulatory resorting of the urban environment inherently is fraught with tensions. It calls into question a widely accepted understanding of the separation of urban and rural life (Blecha, 2007; Gaynor, 2007). The more permissible the code, the greater the chances that a conflict among neighbors with differing perspectives on urbanism will ensue.

And yet, in most cases, this experimentation only marginally pushes the boundaries of the urbanrural delineation. Twelve of the 22 cities included in this study use highly restrictive zoning, all of the municipalities use at least one relatively stringent site-level restriction, and language concerning nuisance often puts the onus on the livestock keeper to avoid potential conflicts with surrounding land uses. It is rare to find a municipality that is widely permissive in all aspects of urban livestock keeping. Even in the case of chickens, which are allowed in every municipality in this study, the keeping of fowl in residential areas is highly regulated with setbacks, number limits, permitting processes, and detailed management specifications. Nonetheless, these steps, while tentative, are bringing old arguments about defining life in town versus life in the country back to the surface. A resorting of the urban environment is beginning in some U.S. municipalities.

\section{Urban Livestock and Public Health}

In some ways, the tentativeness can be explained by a more fundamental challenge in welcoming livestock back to the city. The rural-urban divide was created not simply because city dwellers thought it would be nicer that way, but rather because public officials sought to reduce incidence of disease and unsanitary living conditions that could accompany agricultural activities in densely populated urban areas (Blecha, 2007; Gaynor,
2007; Orbach \& Sjoberg, 2011a). As gardens and livestock grow in popularity and return to the city, old tensions resurface. As one of the reviewers of this paper commented, "As a public health nurse involved in urban agriculture, I often feel torn between wanting to encourage growing of local foods and raising animals in the city and potential health risks. We are as healthy as we are in part due to the separation of animals and people" (personal communication from anonymous manuscript reviewer, September 22, 2011). This is a core concern that municipalities seek to address in municipal codes that regulate livestock keeping in urbanized areas.

Municipalities wishing to avoid public health concerns and social conflict associated with urban livestock altogether can choose to simply prohibit certain animal types from city limits. However, based on the ordinances in this study, animal type prohibitions were used as much or more for reducing social conflict from other types of nuisance, such as those associated with noise or odors, as they were for public health concerns. A frequently prohibited animal, the rooster, poses no more public health threat than chickens, which are widely allowed. Zoning and site-level restrictions may have been developed with an eye toward public health concerns as well as nuisance. However, code language most directly addresses public health in outlining management specifications for animal keeping practices in the public health or animal control sections of the code.

At the level of livestock keeping practices, the municipalities in this study approached dealing with public health concerns in one of two ways. The most widely used approach provides very explicit and detailed language about how the animals are to be kept, how wastes are to be handled, and what pest control measures should be in place. The codes in this study frequently utilize provisions such as keeping feed covered in coyote- or ratproof containers, disposing of wastes in ways to minimize odors and contamination of waterways, and destroying diseased animals. Many of the codes prohibit the slaughter of animals on site. Codes also clarify the involvement of health departments 
or other code enforcement officials in determining when health or animal treatment concerns need to be addressed.

In the second approach, the codes specify the enforcement official and use vague language to describe what constitutes a nuisance or health violation. In these cases, urban livestock keepers have little specific guidance on what they should do to meet the provisions of the code. Instead, the code allows for some flexibility, providing a level of discretion to the administrative overseer and the urban farmer to work out how to best manage urban livestock on a specific piece of land.

The difference between these two approaches is striking. In the first case, clarity and predictability is high, but where specifications are overly stringent, cost prohibitive or inapplicable on a particular plot, some individuals will be unable to engage in the practice of livestock keeping where they live. In the second case, the flexibility of the ordinance allows for creativity as landowners work with public officials to determine the best ways to minimize nuisance and health concerns based on the specific conditions of the proposed urban livestock activity. Such flexibility also could lead to inconsistent application of the intent of the law which could be construed as unfair or capricious.

One approach is not inherently more or less likely to achieve public health goals or minimize the risk of nuisance in relation to urban livestock keeping. Each sets up a process through which urban livestock keepers and administrative overseers will proceed before the practice will be allowed or terminated. In the end, the practices of administrators and urban farmers will determine the extent to which public health concerns are effectively mitigated. However, these concerns can be addressed through careful crafting and enforcement of ordinances, along with the effective identification of instances of health problems. The more public health conflicts can be curtailed through these ordinances and their enforcement, the more likely the practice of urban livestock keeping will expand to other communities.

\section{Conclusion}

Municipal governments and planners are likely to face increasing pressure to address the question of urban livestock. As they do so, they will have to figure out how to navigate the inherent tensions that come with animal husbandry in urban and semi-urban environments and determine whether and how to allow the return of livestock animals to the city.

The return of livestock to the city calls into question the dominant perspective that separates urban life from rural life and brings up concerns about public health impacts of urban livestock. The separation of urban and rural is being challenged by those who choose to keep animals in urban and semi-urban areas (Blecha, 2007) as well as by municipalities that have chosen to allow and enable such activities (Gaynor, 1999, 2007). The underlying narrative of what it means to be an urban dweller has the potential to be reshaped with a new focus on self-reliance, urban resilience, and food production. This transition will only happen in places where municipal officials choose to develop ordinances where urban livestock is permissible and where livestock keeping is undertaken in ways that result in minimal social conflict and public health impacts. Codes will have to address public health concerns related to animal wastes, contaminated stormwater runoff, pestilence and diseases related to all of these.

There is no simple answer to these concerns. Each of the municipal codes analyzed here navigates this complex terrain differently. Some set such restrictive zoning, large lot sizes, and/or expansive setbacks that only residents on the periphery are likely to engage in livestock keeping, unless large undeveloped plots remain (or reemerge, in the case of shrinking cities) in more urbanized areas. Others provide strict guidelines for animal confinement, care, and facilities maintenance while remaining relatively permissive on type, lot size, setback, and number limitations. Still others provide guidelines and set limits, but allow landowners and officials to take into account the particularities of the animals, site conditions, and surroundings and make a judgment about the appropriateness of animal hus- 
bandry on a case-by-case basis. There is no single approach, but every locality in this study incorporated some level of administrative oversight and legal restrictions on livestock activities within municipal boundaries, primarily to address issues of public health and nuisance concerns. Taken together, these ordinances offer a variety of options that municipal officials can draw on as they seek to determine whether and how to welcome animals back to the city.

These efforts inherently are shaped by local and regional social, political, and economic realities. The call for local food may be harmonious, but the responses are necessarily cacophonic. As these experiments in urban livestock play out, it will be instructive to watch which places navigate the challenges of welcoming livestock back into the city most effectively, simultaneously allowing urban livestock keeping while minimizing nuisance and public health conflicts. The success or failure of these early experiments will determine how widespread the practice of urban livestock keeping is likely to become and the extent to which municipalities will welcome animals back into the urban environment.

\section{Acknowledgements}

I wish to thank two graduate students in the Department of Urban and Regional Planning of Florida State University, Chelsea Whitcomb and Susanna Sovran, for their assistance in locating and analyzing municipal codes for this project. Their help was invaluable in completing this work.

\section{References}

Blecha, J. L. (2007). Urban life with livestock: Performing alternative imaginaries through small-scale urban livestock. agriculture in the United States (Doctoral dissertation). Retrieved from ProQuest (UMI No. 3273113).

Born, B., \& Purcell, M. (2006). Avoiding the local trap: Scale and food systems in planning research. Journal of Planning Education and Research, 26(2), 195-207. http://dx.doi.org/10.1177/0739456X06291389

Campbell, M. C. (2004). Building a common table: The role for planning in community food systems. Journal of Planning Education and Research,
23(4), 341-355.

http://dx.doi.org/10.1177/0739456X04264916

Carpenter, N. (2009). Farm city: The education of an urban farmer. London: Penguin Books.

Charmaz, K. (2006). Constructing grounded theory: A practical guide through qualitative analysis. Thousand Oaks, California: Sage Publications.

City of Minneapolis Community Planning and Economic Development Department. (2011). Urban agriculture policy plan: $A$ land use and development plan for a bealthy, sustainable local food system.

Minneapolis, Minnesota: Author. Retrieved from http://www.minneapolismn.gov/cped/planning/ plans/cped_urban_ag_plan

Cronon, W. (1991). Nature's metropolis: Chicago and the Great West. New York: Norton Publishing.

Delind, L. B. (2011). Are local food and the local food movement taking us where we want to go? Or are we hitching our wagons to the wrong stars? Agriculture and Human Values, 28(2), 273-283. http://dx.doi.org/10.1007/s10460-010-9263-0

Diamond, J. (2005). Collapse: How societies choose to fail or succeed. New York: Viking.

Dunkley, B., Helling, A., \& Sawicki, D. S. (2004). Accessibility versus scale: Examining the tradeoffs in grocery stores. Journal of Planning Education and Research, 23(4), 387-401. http://dx.doi.org/10.1177/0739456X04264890

Gaynor, A. (1999). Regulation, resistance and the residential area: The keeping of productive animals in twentieth-century Perth, Western Australia. Urban Policy and Research, 17(1), 7-16. http://dx.doi.org/10.1080/08111149908727786

Gaynor, A. (2007). Animal agendas: Conflict over productive animals in twentieth-century Australian cities. Society and Animals, 15(1), 29-42. http://dx.doi.org/10.1163/156853007X169324

Glaeser, E. (2011, June 16). The locavore's dilemma: Urban farms do more harm than good to the environment. Boston Globe. Retrieved from http://articles.boston.com/2011-06-16/ bostonglobe/29666344 1 greenhouse-gas-carbonemissions-local-food

Goldstein, M., Bellis, J., Morse, S., Myers, A., \& Ura, E. (2012). Urban agriculture: $A$ sixteen city survey of urban agriculture practices across the country. Atlanta, Georgia: Emory University, Turner Environmental Law Clinic. 
Hodgson, K., Campbell, M. C., \& Bailey, M. (2011). Urban agriculture: Growing healthy, sustainable places (Vol. 563). Chicago, Illinois: American Planning Association.

Kaufman, J. (2004). Introduction. Journal of Planning Education and Research, 23, 335-340. http://dx.doi.org/10.1177/0739456X04264897

Kuruvila, M. (2011, May 9). Oakland urban farming prompts plan to redo rules. San Francisco Chronicle. Retrieved from http://www.sfgate.com/cgibin/article.cgi? $\mathrm{f}=/ \mathrm{c} / \mathrm{a} / 2011 / 05 / 08 / \mathrm{BA7O1J74O5.}$ DTL\&tsp $=1$

LaBadie, K. (2008). Residential urban chicken keeping: An examination of 25 cities. University of New Mexico. Retrieved from http://urbanchickens.org/files/ Ordinance $\% 20$ research $\% 20$ paper.pdf

Meeus, S. J., \& Gulinck, H. (2008). Semi-urban areas in landscape research: A review. Living Reviews in Landscape Research, 2, 3.

Mendes, W., Balmer, K., Kaethler, T., \& Rhoads, A. (2008). Using land inventories to plan for urban agriculture: Experiences from Portland and Vancouver. Journal of the American Planning Association, 74(4), 435-449. http://dx.doi.org/10.1080/01944360802354923

Miles, M. B., \& Huberman, A. M. (1994). Qualitative data analysis: An expanded sourcebook (Second Ed.). Thousand Oaks, California: Sage Publications.

Nestle, M. (2006). What to eat. New York: North Point Press.

Orbach, B. Y., \& Sjoberg, F. R. (2011a). Excessive speech, civility norms, and the clucking theorem. Connecticut Law Review, 44(1); Arizona Legal Studies Discussion Paper No. 11-01. Available at SSRN: http://ssrn.com/abstract=1740625

Orbach, B. Y., \& Sjoberg, F. R. (2011b). Debating over backyard chickens. Arizona Legal Studies Discussion Paper (No. 11-02), 1-20. http://dx.doi.org/10.2139/ssrn.1742930

Pollan, M. (2006). The omnivore's dilemma: A natural bistory of four meals. New York: Penguin Press.

Pothukuchi, K., \& Kaufman, J. L. (1999). Placing the food system on the urban agenda: The role of municipal institutions in food systems planning. Agriculture and Human Values, 16(2), 213-224. http://dx.doi.org/10.1023/A:1007558805953
Randolph, J. (2012). Environmental land use planning and management. Washington, D.C.: Island Press.

Salkin, P. (2011). Feeding the locavores, one chicken at a time: Regulating backyard chickens. Zoning and Planning Law Report, 34(3), 1-12.

Schiere, H., \& Hoek, R. v. d. (2001). Livestock keeping in urban areas: A review of traditional technologies based on literature and field experiences. New York, New York: United Nations Food and Agriculture Organization.

Schiere, H., Thys, E., Matthys, F., Rischkowsky, B., \& Schiere, J. (2006). Livestock keeping in urbanised areas, does history repeat itself? In R. van Veenhuizen (Ed.), Cities farming for the future: Urban agriculture for green and productive cities (pp. 347-378). Philippines: International Institute of Rural Reconstruction and ETC Urban Agriculture.

Schlosser, E. (2001). Fast food nation: The dark side of the all-American meal. New York, New York: Perennial.

Smit, J., Nasr, J., \& Ratta, A. (2001). Urban agriculture: Food, jobs, and sustainable cities. Retrieved from http://www.jacsmit.com/book.html

Steel, C. (2009). Hungry city: How food shapes our lives. London: Vintage Books.

U.S. Department of Agriculture (USDA) Agricultural Marketing Service. (2011). Farmers markets and local food marketing: Farmers market growth 1994-2010. Retrieved April 19, 2011, from http://www.ams.usda.gov/AMSv1.0/ams.fetchTe mplateData.do?template $=$ TemplateS\&navID $=$ Who lesaleandFarmersMarkets\&leftNav $=$ WholesaleandF armersMarkets\&page $=$ WFMFarmersMarketGrowt h\&description=Farmers $\% 20$ Market $\% 20$ Growth\&a cct $=$ frmrdirmkt

Vallianatos, M., Gottlieb, R., \& Haase, M. A. (2004). Farm-to-school: Strategies for urban health, combating sprawl, and establishing a community food systems approach. Journal of Planning Education and Research, 23, 414-423. http://dx.doi.org/10.1177/0739456X04264765

Village of Euclid v. Ambler Realty Co., 272 U.S. 365 (1926).

Wekerle, G. R. (2004). Food justice movements: Policy, planning, and networks. Journal of Planning Education and Research, 23, 378-386. http://dx.doi.org/10.1177/0739456X04264886 


\section{Appendix. Sources for Ordinances}

\begin{tabular}{|c|c|c|}
\hline Municipality & State & Source for Ordinance \\
\hline Ann Arbor & Michigan & $\begin{array}{l}\text { Ann Arbor Code of Ordinances } \\
\text { Title IX, Ch. 107, Sec. } 9.38-39,9.42 \\
\text { Adopted October 4, } 2010 \\
\text { http://library.municode.com/index.aspx?clientld=11782\&stateld=22\&stateName= } \\
\text { Michigan }\end{array}$ \\
\hline Baltimore & Maryland & $\begin{array}{l}\text { Baltimore Zoning Code Draft } 2010 \\
\text { Title 14-2, Sec. } 14-305,14-327 \\
\text { http://www.rewritebaltimore.org/home.html } \\
\text { Baltimore City Health Code } \\
\text { Title 2, Sec. } 2-106 \text {, Title 10, Subtitles 1, 3, 6, Sec. 10-106 } \\
\text { Effective October 6, } 2007 \\
\text { http://www.baltimorehealth.org/press/2007 } 0202 \text { AnimalRegs.pdf }\end{array}$ \\
\hline Bloomington & Indiana & $\begin{array}{l}\text { Bloomington Municipal Code } \\
\text { Title 20, Chapter 20.05, Sec. 20.05.089-095 } \\
\text { Passed December 15, } 2010 \\
\text { http://bloomington.in.gov/code/ }\end{array}$ \\
\hline Charlotte & North Carolina & $\begin{array}{l}\text { Code of Ordinances, Charlotte, NC } \\
\text { Part II, Chapter 3, Article IV, Sec. 3-102 } \\
\text { Updated December 13, } 2004 \\
\text { Appendix A, Chapter 9, Part } 1 \\
\text { Updated most recently, September 20, } 2010 \\
\text { http://library.municode.com/index.aspx?clientld=19970\&stateld=33\&stateName=North } \\
\underline{\text { Carolina }}\end{array}$ \\
\hline Chattanooga & Tennessee & $\begin{array}{l}\text { Chattanooga City Code } \\
\text { Appendix B, Article V, Sec. 1600-1604 } \\
\text { January } 2009 \\
\text { http://www.chattanooga.gov/City Council/110 Code.asp }\end{array}$ \\
\hline Cleveland & Ohio & $\begin{array}{l}\text { The Code, City of Cleveland } \\
\text { Part 3, Title VII, Ch. } 347 \text {, Sec. } 347.02 \\
\text { Adopted June 30, } 2010 \\
\text { http://planning.city.cleveland.oh.us/zoning/pdf/34702FarmAnimalsandBees.pdf }\end{array}$ \\
\hline Detroit & Michigan & $\begin{array}{l}\text { Detroit City Code } \\
\text { Part III, Ch. 6, Art. 1, Sec. 6-1-3 } \\
\text { Enacted November 23, 2010 } \\
\text { http://library.municode.com/index.aspx?clientld=10649\&stateld=22\&stateName= } \\
\text { Michigan }\end{array}$ \\
\hline Fort Collins & Colorado & $\begin{array}{l}\text { Fort Collins Municipal Code } \\
\text { Ch. 4, Art. II, Div. 6, Sec. 4.116-117, Art. III, Div. 2, Sec. 4.226-236 } \\
\text { Includes ordinances through December 21, } 2010 \\
\text { http://www.colocode.com/ftcollins/municipal/begin2.htm\#toc }\end{array}$ \\
\hline
\end{tabular}




\begin{tabular}{|c|c|c|}
\hline Municipality & State & Source for Ordinance \\
\hline Kansas City & Missouri & $\begin{array}{l}\text { Code of Ordinances, City of Kansas City } \\
\text { Part II, Chapter 14, Sec. } 14-12 \text { through 14-15, Ch. 34, Sec. 34-21 } \\
\text { Enacted March 10, } 2011 \\
\text { http://library.municode.com/index.aspx?clientld=10156\&stateld=25\&stateName= } \\
\text { Missouri }\end{array}$ \\
\hline Longmont & Colorado & $\begin{array}{l}\text { Municipal Code f City of Longmont } \\
\text { Title 7, Sec. } 7.04 .130, \text { Title 9, Sec. } 9.04 .020 \\
\text { Adopted February 8, } 2011 \\
\text { http://library.municode.com/index.aspx?clientld=14590\&stateld=6\&stateName= } \\
\underline{\text { Colorado }}\end{array}$ \\
\hline Madison & Wisconsin & $\begin{array}{l}\text { Madison Code of Ordinances } \\
\text { Ch. } 7, \text { Sec. } 7.29, \text { Ch. } 9, \text { Sec } 9.52, \text { Ch. } 23, \text { Sec. } 23-31 \\
\text { No date specified } \\
\text { http://library.municode.com/index.aspx?clientld=50000\&stateld=49\&stateName= } \\
\text { Wisconsin }\end{array}$ \\
\hline Missoula & Montana & $\begin{array}{l}\text { Missoula Municipal Code } \\
\text { Title 6, Sec. } 6.12 .010-030 \\
\text { This chapter updated July 9, } 2008 \\
\text { http://www.ci.missoula.mt.us/index.aspx?nid=268 }\end{array}$ \\
\hline Mobile & Alabama & $\begin{array}{l}\text { Code of Ordinances, City of Mobile } \\
\text { Ch. 7, Art. IV, Div. 1, Sec. 7.81-95, Div. 2, Sec. 7.101-113, Ch. 64, Sec. 64.1-11 } \\
\text { Enacted January 18, } 2011 \\
\text { http://library.municode.com/index.aspx?clientld=11265\&stateld=1\&stateName= } \\
\text { Alabama }\end{array}$ \\
\hline Morgan Hill & California & $\begin{array}{l}\text { Morgan Hill Municipal Code } \\
\text { Title 6, Ch. 6.36, Sec. 6.36.040-6.36.180, 6.36.270-6.36.280 } \\
\text { Passed November 17, } 2010 \\
\text { http://library.municode.com/index.aspx?clientld=16502\&stateld=5\&stateName= } \\
\text { California }\end{array}$ \\
\hline Mountain View & California & $\begin{array}{l}\text { Mountain View City Code } \\
\text { Part II, Ch. 5, Div. 2, Art. II, Sec. 5.46-59, Ch. 36, Art. XII, Sec. A.36.10-20 } \\
\text { Passed March 1, } 2011 \\
\text { http://library.municode.com/index.aspx?clientld=16508\&stateld=5\&stateName= } \\
\text { California }\end{array}$ \\
\hline Rogers & Arkansas & $\begin{array}{l}\text { Code of Ordinances, City of Rogers } \\
\text { Ch. 6, Art. V, Sec. 6-228 through 6-230, Art. VI, Div. 1, Sec. 6-254 through 6-256, Div. 2, } \\
\text { Sec. 6-276 through 6-270, Ch. 14, Art. VI, Div. 2, Sec. 14-696 through 14-734 } \\
\text { Enacted July 27, } 2010 \\
\text { http://library.municode.com/index.aspx?clientld=14712\&stateld=4\&stateName= } \\
\underline{\text { Arkansas }}\end{array}$ \\
\hline Round Rock & Texas & $\begin{array}{l}\text { Code of Ordinances, City of Round Rock } \\
\text { Part II, Ch. 8, Art. 1, Sec. 8-5, 8-6, Art II, Sec. 8-31 } \\
\text { Enacted January 27, } 2011 \\
\text { http://library.municode.com/index.aspx?clientld=14610\&stateld=43\&stateName=Texas }\end{array}$ \\
\hline
\end{tabular}


Journal of Agriculture, Food Systems, and Community Development ISSN: 2152-0801 online

www.AgDevjournal.com

\begin{tabular}{|c|c|c|}
\hline Municipality & State & Source for Ordinance \\
\hline San Antonio & Texas & $\begin{array}{l}\text { Code of Ordinances, City of San Antonio } \\
\text { Part II, Ch. 5, Art. III, Sec. 5.50-5.52, Art. V, Sec. 5.109, 5.114 } \\
\text { Enacted January 20, } 2011 \\
\text { http://library.municode.com/index.aspx?clientld=11508\&stateld=43\&stateName=Texas }\end{array}$ \\
\hline Santa Clara & California & $\begin{array}{l}\text { Santa Clara City Code } \\
\text { Title 6, Ch. 6.15, Sec. 6.15.010-060, Title 8, Ch. 18.04, Sec. 18.04.010-040 } \\
\text { http://www.codepublishing.com/ca/santaclara/frameless/ }\end{array}$ \\
\hline Seattle & Washington & $\begin{array}{l}\text { Seattle Municipal Code } \\
\text { Title 23, Subtitle III, Chapter 23.42, Sec. 23.42.052 } \\
\text { Includes amendments passed through December } 2010 . \\
\text { http://library.municode.com/index.aspx?clientld=13857 }\end{array}$ \\
\hline South Portland & Maine & $\begin{array}{l}\text { South Portland Code of Ordinance } \\
\text { Ch. 3, Art. II, Sec. 3-52 through 3-67, Art. III, Sec. 3-71 through 3-93 } \\
\text { Include amendments passed through December } 2010 \\
\text { http://www.southportland.org/index.asp?Type=B LIST\&SEC=\{93286E1E-9FF8-40D2- } \\
\text { AC30-8840DEB23A29\} }\end{array}$ \\
\hline Stamford & Connecticut & $\begin{array}{l}\text { City of Stamford, Zoning Regulations, Section 5-1, } \\
\text { http://www.cityofstamford.org/filestorage/25/52/138/164/204/Stamford Zoning Regu } \\
\text { lations_9-17-10.pdf } \\
\text { Stamford Connecticut, Code of Ordinances, Chapter 111, Sec. 111-2 through 11-6 } \\
\text { http://library.municode.com/index.aspx?clientld=13324\&stateld=7\&stateName= } \\
\text { Connecticut }\end{array}$ \\
\hline
\end{tabular}


Journal of Agriculture, Food Systems, and Community Development ISSN: 2152-0801 online www.AgDevJournal.com 